\title{
The effects of return on investment, sales growth rate, volatility of investment, cash flow and structure of institutional shareholders on the ratio of debt to equities
}

\author{
Jalal Golmohammadi ${ }^{\mathrm{a}}$ and Mahboubeh Jafari ${ }^{\mathrm{b}}$
}

\begin{abstract}
${ }^{a}$ Master Student, Department of Management and Accounting, South Tehran Branch, Islamic Azad University, Tehran, Iran ${ }^{b}$ Faculty Member, Department of Management and Accounting, South Branch, Islamic Azad University, Tehran, Iran

C H R O N I C L E

\begin{tabular}{l}
\hline Article history: \\
Received June 5, 2015 \\
Received in revised format \\
August 162015 \\
Accepted November 82015 \\
Available online \\
November 102015 \\
\hline Keywords: \\
Tehran Stock Exchange \\
Return on investment \\
Growth rate
\end{tabular}
A B S T R A C T

This paper presents a study to measure the effects of return on investment, sales growth rate, volatility investment, cash flow and structure of institutional shareholders on the ratio of debt to equities. The study selects 102 firms listed on Tehran Stock Exchange and, using regression technique with Panel data, examines five different hypotheses over the period 2008-2012. The results indicate that there was a negative and meaningful relationship between return of investment and the ratio of debt to equities and a positive and meaningful relationship between sales growth and the ratio of debt to equities. Moreover, there were positive and meaningful relationships between volatility of investment as well as cash flow and the ratio of debt to equities. Finally, the survey has indicated that there was a negative and meaningful relationship between the structure of institutional shareholders and the ratio of debt to equities.
\end{abstract}

\section{Introduction}

One of the most important issues on management of firms is to determine an appropriate method for financing activities by either raising fund directly from shareholders or borrowing it from financial institutions (Fazzari et al., 1987; Devereux \& Schiantarelli, 1990). The ratio of debt to equities is always an important factor for business development. A small ratio of debt to equities means the firm has a high risk of financing while a low ratio means a low return on investment (Hoshi et al., 1991). There are many studies to determine the effects of various factors on the ratio of debt to equities. Minton and Schrand (1999) demonstrated that higher cash flow volatility could be associated with lower average levels of investment in capital expenditures, $\mathrm{R} \& \mathrm{D}$, and advertising. This association implies that companies do not implement external capital markets to cover cash flow shortfalls. Cash flow volatility in this survey was related to higher costs of reaching external capital. In addition, these higher expenses, as measured by some proxies, indicate a bigger sensitivity of investment to cash flow volatility.

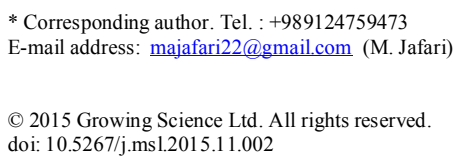


Richardson (2006) investigated the extent of company level over-investment of free cash flow and reported some results, which were consistent with agency expense description, where over-investment is associated with firms with high levels of free cash flow. Attig et al. (2012) studied the relevance of institutional investors' investment horizon and argues that institutional investors with longer investment horizons had bigger incentives and efficiencies to involve in effective monitoring.

Wang et al. (2015) investigated the impact of company investment on stock returns by implementing data on the Chinese stock market. They discovered that firms with bigger investment experience lower future returns and there was an obvious investment impact in the Chinese stock market. The investment impact was appeared to be stronger for companies that had bigger cash flows, lower debt or for stateowned companies. They also investigated the relationship between investment and returns and reported that the high investment companies tend to earn higher returns than low investment ones before portfolio formation; however the high investment companies earn lower returns than low investment ones after portfolio formation. Moreover, the stock returns may not necessarily change after investment, and the stock returns may not substantially correlate with firm profitability positively.

Davis (2014) considered whether debt-based capital inflows maintained various impacts on many shortrun macroeconomic indicators than equity-based capital inflows. They estimated the response of domestic variables to an exogenous shock to debt. In their survey, "an exogenous increase in debt inflows leads to a substantial increase in the output gap, inflation, stock prices and credit growth and an appreciation of the exchange rate". Pech et al. (2015) proposed a set of "most preferred" financial ratios from equity analysts covering Mexican publicly traded companies in Mexico. They reported that the most preferred ratios by equity analysts were not actually those ratios basically covered in financial textbooks.

Chernykh and Cole (2015) examined the predictive power of several alternative measures of bank capital adequacy in determining U.S. bank failures. They reported that the non-performing asset coverage ratio (NPACR) could substantially outperforms Basel-based. They stated this measure promise its effective implementation in the prompt corrective actions by bank regulators. Louati et al. (2015) investigated the behavior of Islamic and conventional banks in association with the ratio of the capital adequacy in various competitive conditions. They reported that the funding ratio could substantially influence on the behavior of 70 conventional banks and 47 Islamic banks. Nevertheless, competitive conditions maintained no substantial impact on the relationship between the weighted assets ratio and Islamic bank behavior.

\section{The proposed study}

This paper presents a study to measure the effects of return on investment, sales growth rate, volatility investment, cash flow and structure of institutional shareholders on the ratio of debt to equities. The study randomly selects 102 firms listed on Tehran Stock Exchange and, using regression technique with Panel data, examines five different hypotheses over the period 2008-2012. In our selection strategy, we choose only the actively traded firms whose fiscal calendar fits with solar year and their information are available. The proposed study also do not consider the information of holding firms.

The proposed study considers the following five hypotheses,

1. There is a relationship between the return of investment and the ratio of debt to equities.

2. There is a relationship between the sales growth rate and the ratio of debt to equities.

3. There is a relationship between the volatility of investment and the ratio of debt to equities.

4. There is a relationship between the standardized cash flow and the ratio of debt to equities. 
5. There is a relationship between the structure of institutional shareholders and the ratio of debt to equities.

The proposed study of this paper considers the ratio of debt to equities as dependent variable and return of investment, sales growth rate, volatility of investment, standardized cash flow and structure of institutional shareholders are considered as dependent variables. In addition, three variables of cumulative abnormal returns, size of firms and other financial limitations are control variables. The ratio of debt to equities is measured by total liabilities divided by total equities. Return of investment is also calculated as follows,

$$
(C K / K)_{i, t}=\frac{\text { Total liabilities }}{\text { Change in total assets between two consecutive }} .
$$

The proposed study calculates change in sales $(y / K)_{i, t}$ as follows,

$$
(y / K)_{i, t}=\frac{\text { Sales }_{i, t}-\text { Sales }_{i, t-1}}{\text { Sales }_{i, t-1}} .
$$

The survey considers the following to calculate the change in investment

$$
(V I / K)_{i, t}=\frac{\text { Investment in current year }- \text { Investment in previous year }}{\text { Investment in previous year }} .
$$

Standardized cash flow is also calculated as follows,

$$
\begin{aligned}
& (C F / K)_{i, t}=E_{i, t}+T A C C_{i, t}, \\
& T A C C_{i, t}=\Delta T A_{i, t}+\Delta C A S H_{i, t}-\Delta T L_{i, t}+\Delta P S_{i, t},
\end{aligned}
$$

where $(C F / K)_{i, t}$ represents standardized cash flow, $E_{i, t}$ denotes Net profit before extraordinary items, $T A C C_{i, t}$ represents total accruals, $\triangle T A_{i, t}$ shows the growth on total assets, $\triangle C A S H_{i, t}, \Delta T L_{i, t}$ and $\triangle P S_{i, t}$ show changes on available cash, total liabilities and purchase on shares of the firms in two consecutive years, respectively. Finally, the ratio of institutional ownership is follows,

$$
(\text { Lars })_{i, t}=\frac{\text { shares owned by institutions }}{\text { total number of outstanding shres }} \text {. }
$$

As state earlier, cumulative abnormal returns is a control variable, which is calculated as follows,

$$
(C R / K)_{i, t}=\mathrm{R}_{\mathrm{it}}-\mathrm{R}_{\mathrm{mt}}
$$

where the return of each firm is calculated as follows,

$$
\mathrm{R}_{\mathrm{it}}=\frac{\left(\mathrm{P}_{\mathrm{it}}-\mathrm{P}_{\mathrm{it}-1}\right)+\mathrm{DPS}+\left(\mathrm{P}_{\mathrm{it}}-1000\right) \mathrm{A}+\mathrm{P}_{\mathrm{it}} \mathrm{B}}{\mathrm{P}_{\mathrm{it}-1}} \times 100
$$

where $P_{i t}$ and $P_{i t-1}$ are closing prices for two consecutive years, DPS represents dividend paid to shareholders, $A$ denotes the raising equity capital from cash and finally $B$ denotes the raising equity capital from retained earnings and reserves. In our survey, market returns is calculated as follows,

$$
\mathrm{R}_{\mathrm{mt}}=\frac{\text { TEPIX }_{\mathrm{t}}-\mathrm{TEPIX}_{\mathrm{t}-1}}{\text { TEPIX }_{\mathrm{t}-1}} \times 10
$$

where TEPIX is an official index for Tehran Stock Exchange. 
In our survey, size of the firm ( SFirm $\left._{i, t}\right)$, as control variable, is calculated by taking natural logarithm on total assets.

Moreover, financial limitations $\left(W W i n d e x_{i, t}\right)$, also denoted as $C_{\text {ons }} F_{i, t}$, is also calculated as follows (Baker \& Wurgler, 2007),

$$
\begin{aligned}
& \text { WWindex }_{i, t}=-0.091 \text { CashFlow }_{i, t}-0.062 \text { DIVPOS }_{i, t}+0.021 \text { TLTD }_{i, t}-0.044 \text { Size }_{i, t} \\
& +0.102 \text { ISG }_{i, t}-0.035 S G_{i, t}
\end{aligned}
$$

where CashFlow is the ratio of cash flow, which is calculated as follows,

$$
\text { CashFlow }_{i, t}=\frac{\text { Net cash flows from operating activities }}{\text { Book value of total assets }}
$$

In addition, $\operatorname{DIVPOS}_{i, t}$ is a dummy variable, which is one if a firm pays dividend in a year and zero, otherwise. $T^{2} T D_{i, t}$ is the ratio of long term liabilities on total assets. Size is the logarithm of total assets. $S G$ and $I S G_{i, t}$ represent the relative growth of sales of firms and industry in two consecutive years, respectively and finally, $\varepsilon_{\mathrm{i}, \mathrm{t}}$ represents the residuals. The proposed study uses the following regression model to examine different hypotheses of the survey.

$$
\begin{aligned}
& (B / k)_{i, t}=\alpha_{0}+\beta_{1}(C K / K)_{i, t}+\beta_{2}(y / K)_{i, t}+\beta_{3}(V I / K)_{i, t}+\beta_{4}(C F / K)_{i, t}+\beta_{5}(\text { Lars })_{i, t}+ \\
& \beta_{6}(C R / K)_{i, t}+\beta_{7} S_{\text {SFrmm }}+\beta_{8} \text { ConsF }_{i, t}+\varepsilon_{\mathrm{i}, t} .
\end{aligned}
$$

\section{The results}

We first present some basic statistics associated with the data gathered in Table 1 as follows,

\section{Table 1}

The summary of some basic statistics

\begin{tabular}{lcccccc}
\hline Variable & Mean & Std. Dev. & Min & Max & Skewness & Kurtosis \\
\hline Debt to equities & 0.4140 & 0.0712 & 0.0331 & 0.5631 & -1.009 & 2.418 \\
Return on investment & 0.7064 & 2.8420 & 0.0116 & 70.7600 & 24.591 & 607.121 \\
Growth in sales & 0.6277 & 0.2354 & 0.0964 & 2.7553 & 2.028 & 14.718 \\
Volatility in Investment & 0.2903 & 0.6654 & 0.0003 & 9.3923 & 8.757 & 91.954 \\
Standardized cash flow & 0.2120 & 0.4901 & -0.0560 & 6.2887 & 8.815 & 89.183 \\
Institutional ownership & 0.0381 & 0.0407 & 0.0000 & 0.4803 & 4.311 & 33.862 \\
Accumulated abnormal return & 0.2482 & 0.1874 & 0.0008 & 0.8786 & 1.058 & 0.697 \\
Firm size & 5.9263 & 0.6189 & 4.7761 & 8.0074 & 0.744 & 0.479 \\
Financial constraint & 0.8954 & 0.3062 & 0.0000 & 1.0000 & -2.591 & 4.728 \\
\hline
\end{tabular}

As we can observe from the results of Table 1, the Kurtosis statistics must be less than 3, which means some variables are not normally distributed. In addition, the implementation of Kolmogorov-Smirnov test yields $\mathrm{K}-\mathrm{S}=1.521$ with Sig. $=0.027$, which also confirms that the dependent variable is not normally distributed. However, after normalizing the operations, we get K-S $=0.601$ with Sig. $=0.862$. Moreover, the implementation of Pearson correlation has confirmed that there was not a strong correlation among independent variables. Table 2 demonstrates the results of the implementation of Chow and Hausman tests for Pool/Panel and Fixed effect versus Random effect.

\section{Table 2}

The summary of Chow and Hausman tests

\begin{tabular}{lccccc}
\hline Test & Number & Statistics & Value & df & P-value \\
\hline Chow & 612 & F & 2.4571 & $(502,101)$ & 0.0392 \\
Hausman & 612 & Chi-Square & 6.1417 & 8 & 0.0314 \\
\hline
\end{tabular}


According to the results of Table 2, fixed effect with Panel method are used for the implementation of the regression technique, which is as follows,

\begin{tabular}{|c|c|c|c|c|c|c|c|c|c|}
\hline t-value & 1.2358 & -1.7463 & 1.5204 & 1.6310 & 1.1000 & -1.7280 & 0.0442 & 1.5689 & -1.0099 \\
\hline Sig. & 0.0472 & 0.0293 & 0.0376 & 0.0183 & 0.0251 & 0.0469 & 0.9647 & 0.0173 & 0.3130 \\
\hline Rel. & $(+)$ & $(-)$ & $(+)$ & $(+)$ & $(+)$ & $(-)$ & meaningless & $(+)$ & meaningless \\
\hline
\end{tabular}

According to the results of regression model, F-value is statistically significant, which means the relationship is linear. In addition, Durbin-Watson value is within desirable level, which means there was no auto-correlation among residuals.

\section{Discussion and conclusion}

The results indicate that there was a negative and meaningful relationship between return of investment and the ratio of debt to equities $(\beta=-0.0017$, $t$-value $=-1.7463)$, a positive and meaningful relationship between sales growth and the ratio of debt to equities $(\beta=0.0046$, $t$-value $=1.5204)$. Moreover, there were positive and meaningful relationships between volatility of investment $(\beta=0.0128$, $t$-value $=$ $1.6310)$ as well as cash flow and the ratio of debt to equities $(\beta=0.0006$, $t$-value $=1.1000)$. Finally, the survey has indicated that there was a negative and meaningful relationship between the structure of institutional shareholders and the ratio of debt to equities $(\beta=-1.7280$, $t$-value $=0.0469)$.

The results of this survey are consistent with the previous studies (Guembel \& White, 2014). For instance, Minton and Schrand (1999) in their survey discussed that higher cash flow volatility could be associated with lower average levels of investment in capital expenditures, R\&D, and advertising. This association implies that companies do not implement external capital markets to cover cash flow shortfalls. Cash flow volatility in this survey was related to higher costs of reaching external capital. In addition, these higher expenses, as measured by some proxies, indicate a bigger sensitivity of investment to cash flow volatility.

\section{Acknowledgement}

The authors would like to thank the anonymous referees for constructive comments on earlier version of this paper.

\section{References}

Attig, N., Cleary, S., El Ghoul, S., \& Guedhami, O. (2012). Institutional investment horizon and investment-cash flow sensitivity. Journal of Banking \& Finance, 36(4), 1164-1180.

Baker, M., \& Wurgler, J. (2007). Investor sentiment in the stock market.

Chernykh, L., \& Cole, R. A. (2015). How should we measure bank capital adequacy for triggering Prompt Corrective Action? A (simple) proposal. Journal of Financial Stability, 20, 131-143

Davis, S. J. (2014). The macroeconomic effects of debt-and equity-based capital inflows. Journal of Macroeconomics, 46, 81-95

Devereux, M., \& Schiantarelli, F. (1990). Investment, financial factors, and cash flow: Evidence from UK panel data. In Asymmetric information, corporate finance, and investment (pp. 279-306). University of Chicago Press.

Fazzari, S., Hubbard, R. G., \& Petersen, B. C. (1987). Financing constraints and corporate investment (No. w2387). National Bureau of Economic Research.

Guembel, A., \& White, L. (2014). Good cop, bad cop: Complementarities between debt and equity in disciplining management. Journal of Financial Intermediation, 23(4), 541-569.

Hoshi, T., Kashyap, A., \& Scharfstein, D. (1991). Corporate structure, liquidity, and investment: Evidence from Japanese industrial groups. The Quarterly Journal of Economics, 106(1), 33-60. 
Louati, S., Abida, I. G., \& Boujelbene, Y. (2015). Capital adequacy implications on Islamic and nonIslamic bank's behavior: Does market power matter?. Borsa Istanbul Review, 15(3), 192-204.

Minton, B. A., \& Schrand, C. (1999). The impact of cash flow volatility on discretionary investment and the costs of debt and equity financing. Journal of Financial Economics, 54(3), 423-460.

Pech, C. O. T., Noguera, M., \& White, S. (2015). Financial ratios used by equity analysts in Mexico and stock returns. Contaduría y Administración,60(3), 578-592.

Richardson, S. (2006). Over-investment of free cash flow. Review of accounting studies, 11(2-3), 159189.

Wang, Y., Liu, C., Lee, J. S., \& Wang, Y. (2015). The relation between asset growth and the crosssection of stock returns: Evidence from the Chinese stock market. Economic Modelling, 44, 59-67. 